\title{
Evaluation of the cytotoxic effects of sodium hypochlorite on human dental stem cells
}

\author{
Shiqi Liu, Hanchao Zhai, Shaoping Fu, Chengyu Cui, Jian Xu, Jinjuan Jiang, \\ Pengyu Pan, Baorong Zhang* \\ Department of Oral Therapy, The Oral Therapy Center Aviation General Hospital, Beijing, 100012, China
}

*For correspondence: Email: Shiqi65828@163.com; Tel: +86-010-59520180

\begin{abstract}
Purpose: To investigate the influence of sodium hypochlorite ( $\mathrm{NaOCl}$ ) on human dental stem cell proliferation and differentiation.

Method: Dental pulp stem cells (DPSCs), periodontal ligament stem cell (PDLSCs), and gingival mesenchymal stem cells (GMSCs) were treated with $\mathrm{NaOCl}$. Cell viability was evaluated with cellular counting kit-8 (CCK8), and cellular adenosine triphosphate (ATP) levels were analyzed by bromodeoxyuridine (BrdU) incorporation and subsequent flow cytometry. Quantitative polymerase chain reaction ( $(P C R)$ and western blotting were performed to detect the expressions of differentiation markers.

Results: The viability and ATP levels of all three stem cells types were impaired by $\mathrm{NaOCl}$ in a concentration- and time-dependent manners. However, the decrease ATP in GMSCs was less than the other two stem cell population $(p<0.05)$. NaOCl treatment significantly suppressed the proliferation of dental stem cells $(p<0.05)$. With regard to differentiation marker expression levels, the decrease in Stro-1 was greater in treatment groups when compared to control on Day 7 , while increase in levels of dentin sialophosphoprotein (DSPP), bone sialoprotein (BSP), and osteocalcin $(O C)$ was smaller $(p<$ $0.05)$. The expressional changes of Stro-1, DSPP, BSP, and OC were more prominent in DPSMs and PDLSCs than in GMSCs.

Conclusion: $\mathrm{NaOCl}$ dose-dependently impairs the viability, proliferation and differentiation of dental stem cells. Thus, its toxicity to dental stem cells needs to be considered in clinical application.
\end{abstract}

Keywords: Dental stem cells, Sodium hypochlorite, Viability, Proliferation, Differentiation

\begin{abstract}
This is an Open Access article that uses a funding model which does not charge readers or their institutions for access and distributed under the terms of the Creative Commons Attribution License (http://creativecommons.org/licenses/by/4.0) and the Budapest Open Access Initiative (http://www.budapestopenaccessinitiative.org/read), which permit unrestricted use, distribution, and reproduction in any medium, provided the original work is properly credited.

Tropical Journal of Pharmaceutical Research is indexed by Science Citation Index (SciSearch), Scopus, International Pharmaceutical Abstract, Chemical Abstracts, Embase, Index Copernicus, EBSCO, African Index Medicus, JournalSeek, Journal Citation Reports/Science Edition, Directory of Open Access Journals (DOAJ), African Journal Online, Bioline International, Open-J-Gate and Pharmacy Abstracts
\end{abstract}

\section{INTRODUCTION}

Sodium hypochlorite $(\mathrm{NaOCl})$, usually used at concentrations from 0.5 to $5.25 \%$, is one of the most frequently used irrigants in regenerative endodontic procedures because of its bactericidal ability and excellent tissue dissolution capacity [1]. Although it is effective and convenient, side effects have been extensively reported in both clinical cases and basic research studies [2]. Previous investigations demonstrated that $\mathrm{NaOCl}$ negatively impacts dental stem cell survival and differentiation [3]. Moreover, the viability of dental 
pulp stem cells (DPSCs) was significantly reduced by $\mathrm{NaOCl}$ in a dose-dependent manner [4]. In vivo studies showed that DPSC differentiation into odontoblast cells was significantly impaired following exposure to 5.25 $\% \mathrm{NaOCl}[5,6]$. Furthermore, $3 \% \mathrm{NaOCl}$ reduced the expression of DSPP by $50 \%$.

Dental pulp stem cells, the first isolated dental stem cells from human permanent third molars, were found to differentiate into osteoblast, chondrocyte- and myoblast like cells $[7,8]$. Periodontal ligament stem cells (PDLSCs) were firstly isolated in 2004 and are capable of differentiating into cementoblast-like cells, adipocytes, fibroblasts, and even neuronal precursors $[9,10]$. Gingival mesenchymal stem cells (GMSCs) were firstly identified in 2010 and are capable of differentiating into [11]. osteoblasts, adipocytes, chondrocytes, endothelial cells, and neurocytes [11-15]. Both dental pulp stem cells and gingival mesenchymal stem cells possess immunomodulatory capabilities based on their interactions with immunocytes, and various toll-like receptors are expressed in GMSCs [16].

Although the effects of irrigants on APSCs have been extensively studied, the exact impacts of $\mathrm{NaOCl}$ on the proliferation and differentiation of DPSCs, PDLSCs, and GMSCs remains largely unknown. The aim of this study was to evaluate the effects of different $\mathrm{NaOCl}$ concentrations and treatment times on viability, proliferation, and differentiation of different dental stem cell types.

\section{EXPERIMENTAL}

\section{Cell culture}

Human dental stem cells (DPSCs, PDLSCs and GMSCs) were purchased from Hongxin Biology Co., Ltd. (China). All stem cells were cultured in 96-well plates at $1 \times 10^{5} /$ well following the manufacturer's instruction. Briefly, cells were cultured in Dulbecco's modified Eagle's medium containing $10 \%$ fetal bovine serum (FBS) and 1 $\%$ penicillin/streptomycin (Gibco, USA) in an incubator with a humidified atmosphere containing $5 \% \mathrm{CO}_{2}$.

\section{$\mathrm{NaOCl}$ treatment}

After $24 \mathrm{~h}$ incubation, the cells were treated with different concentrations of $\mathrm{NaOCl}$ for various periods. The concentrations of $\mathrm{NaOCl}$ was set at $0,0.005,0.025,0.05$, and $0.1 \mathrm{mg} / \mathrm{mL}$, and the time courses were 2, 4, 8, and $24 \mathrm{~h}$. Each condition had three replicates.

\section{Cell viability assay}

Cell viability was assessed using Cell Counting Kit-8 (CCK-8) assays according to the manufacturer's protocol (Dojindo; Tokyo, Japan). $2 \times 10^{3}$ cells were seeded in 96-well plates and incubated at $37^{\circ} \mathrm{C}$ for $2,4,8$, or $24 \mathrm{~h}$ in a humidified chamber containing $5 \% \mathrm{CO}_{2}$. Then, $10 \mu \mathrm{L}$ CCK-8 solution was added to each well, and the plates were incubated for $1 \mathrm{~h}$ at $37^{\circ} \mathrm{C}$. The absorbance of cells at $450 \mathrm{~nm}$ was measured in a microplate reader (Bio-Rad, USA).

\section{Adenosine triphosphate (ATP) assay}

ATP assay kits (Beyotime, China) were used to measure ATP levels according to the manufacturer's instruction. Dental stem cells treated with $\mathrm{NaOCl}$ were lysed with cell lysis buffer $(200 \mu \mathrm{L})$, and centrifuged for $5 \mathrm{~min}$ at $4^{\circ} \mathrm{C}$. Then $100 \mu \mathrm{L}$ working buffer was added to measure the ATP level via luminometer.

\section{Flow cytometry}

DPSCs, PDLSCs, and GMSCs were placed in 96-well plates at $1 \times 10^{5} /$ well. After $24 \mathrm{~h}, \mathrm{NaOCl}$ was added to the cells at $0,0.005,0.01,0.025$, 0.05 , or $0.1 \mathrm{mg} / \mathrm{mL}$. Simultaneously, bromodeoxyuridine (BrdU; Sigma, USA) was added to the cells for $24 \mathrm{~h}$, and flow cytometry was performed to evaluate proliferation. Cells were digested with $0.25 \%$ EDTA-trypsin after three washes with phosphate-buffered saline (PBS), and then fixed with $4 \%$ paraformaldehyde (Huanhai, China) overnight at $4{ }^{\circ} \mathrm{C}$. Next, $0.1 \%$ Triton X-100 (Sigma, USA) was used to permeabilise the cellular membrane at $4{ }^{\circ} \mathrm{C}$ for $10 \mathrm{~min}$. After centrifugation, the cells were incubated with $300 \mu \mathrm{L}$ DNase I at $37^{\circ} \mathrm{C}$ for $30 \mathrm{~min}$ to denature the DNA. The cells were resuspended in $50 \mu \mathrm{L}$ staining buffer and incubated with PE-Mouse anti-BrdU (Thermo Fisher Scientific, USA) and isotype control (Thermo Fisher Scientific) at $4{ }^{\circ} \mathrm{C}$ for $30 \mathrm{~min}$ in the dark. After washing out the staining buffer, the cells were resuspended in PBS and subjected to fluorescence detection.

\section{Quantitative polymerase chain reaction (qPCR)}

DPSCs, PDLSCs, and GMSCs were plated in 6well plates at $1 \times 10^{5} /$ well. After $24 \mathrm{~h}$, the cells were treated with $0.025 \mathrm{mg} / \mathrm{mL} \mathrm{NaOCl}$ for different time points. After three washes with PBS, the medium was replaced with differentiation-induction medium: aMEM plus 10 $\%$ FBS supplemented with dexamethasone (10 nM) (Sigma-Aldrich). The untreated groups were 
taken as control, and all conditions were tested in three replicates. Cells were collected in Trizol at day 0,3 , and 7. cDNA synthesis was performed with PrimeScriptRT reagent kit (Takara, Dalian, China) according to the manufacturer's instructions. Glyceraldehyde 3-phosphate dehydrogenase (GAPDH) was used as the internal control. Primer sequences were listed below:

\begin{tabular}{lll}
\hline Variable & Forward $\left(\mathbf{5}^{\prime}-\mathbf{3}\right.$ ') & res. \\
\hline Osteocalcin & AAGCAGGAGGGCAATAAGGT \\
Forbone & CAACAGCACAGAGGCAGAAA \\
sialoprotein & \\
Dentin & ATATTGAGGGCTGGAATGGGGA \\
GAPDH & GGAGCGAGATCCCTCCAAAAT \\
\hline
\end{tabular}

\section{Western blotting}

Cells were washed three times with PBS and lysed in radioimmunoprecipitation assay buffer with protease inhibitors on ice for $10 \mathrm{~min}$. After centrifugation at $12000 \mathrm{~g}$ for $10 \mathrm{~min}$ at $4{ }^{\circ} \mathrm{C}$, the supernatant was electrophoresed on $12 \%$ sodium dodecyl sulphate gels followed by transfer to polyvinylidene fluoride membranes. The membranes were blocked with $5 \%$ skimmed milk for $2 \mathrm{~h}$ at room temperature, and then incubated with primary antibodies at 1:1000 for Stro-1 (Santa Cruz Biotechnology, USA), 1 DSPP (Abcam, UK) and OC (Sigma, USA). Mouse actin was used as the loading control. After three 5-min washes in PBS-Tween (PBST), the membranes were incubated with secondary antibodies at ilution of 1:2000 for $1 \mathrm{~h}$ at room temperature. Protein signals were visualized by chemiluminescence after three 5 -min washes in PBST.

\section{Statistical analysis}

Data are expressed as mean \pm standard deviation. Statistical analyses comparing two groups were performed using Student's t-tests using SPSS 16.0 software (SPSS Inc., Chicago, IL). Comparisons between multiple groups were performed using one-way analysis of variance followed by least significant difference post hoc tests. Differences were considered statistically significant at $p<0.05$.

\section{RESULTS}

\section{$\mathrm{NaOCl}$ impairs dental stem cell viability}

After $\mathrm{NaOCl}$ treatment, the viabilities of all the three dental stem cell types were significantly lower, especially those treated at high concentration for long incubation times. There was no significant change in DPSC viability at
$\mathrm{NaOCl}$ concentration of $0.005 \mathrm{mg} / \mathrm{mL}$ when the cells were treated for $2 \mathrm{~h}$, whereas viabilities decreased by about 20 and $40 \%$ at 0.01 and $0.05 \mathrm{mg} / \mathrm{mL} \mathrm{NaOCl}$, respectively (Figure $1 \mathrm{~A}$ ). At $24 \mathrm{~h}$, DPSC viabilities decreased by $20,30,60$, 70 , and $80 \%$ at concentrations of $0.005,0.01$, $0.025,0.05$, and $0.1 \mathrm{mg} / \mathrm{mL}$, respectively. With regard to time, cell death rates of DPSCs after 2 , 4,8 , and $24 \mathrm{~h}$ in $0.01 \mathrm{mg} / \mathrm{mL} \mathrm{NaOCl}$ reached up to $20,40,60$, and $70 \%$, respectively. Similar

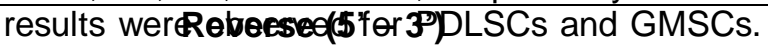

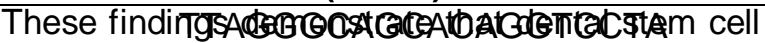

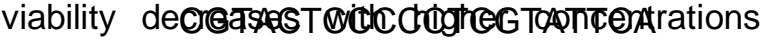
and longer times of $\mathrm{NaOCl}$ treatment.

$A$

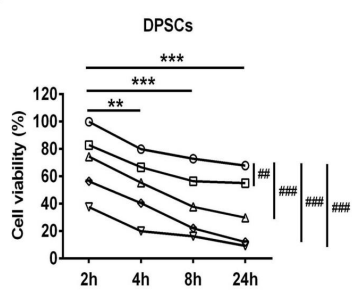

B
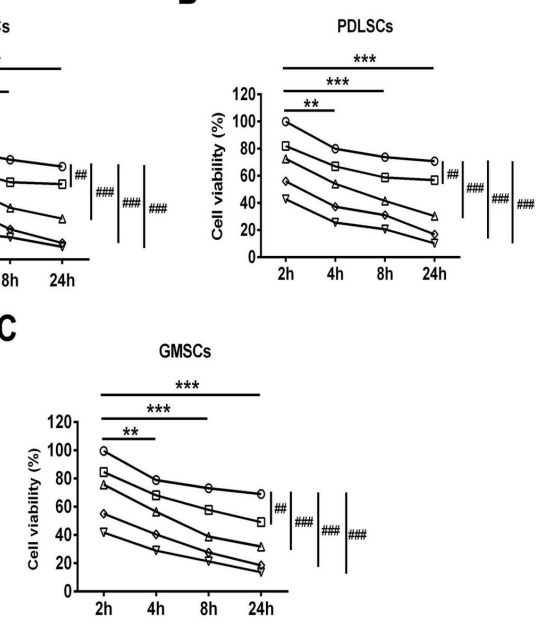

Figure 1: $\mathrm{NaOCl}$ treatment reduced the viability of DPSCs (A), PDLSCs (B), and GMSCs (C). Cells were collected at the indicated time points for viability analyses. Untreated group was taken as control and each condition was tested in triplicate ${ }^{* *}$ or \#\# $p<$ $0.01^{* \star *}$ or \#\#\# $\left.\mathrm{p}<0.001\right)$. $\nabla: 0.1 \mathrm{mg} / \mathrm{mL} \mathrm{NaOCl}$; $\diamond$ : $0.05 \mathrm{mg} / \mathrm{mL} \mathrm{NaOCl} ; \Delta: 0.025 \mathrm{mg} / \mathrm{mL} \mathrm{NaOCl}$; $: 0.01$ $\mathrm{mg} / \mathrm{mL} \mathrm{NaOCl} ; \circ: 0.005 \mathrm{mg} / \mathrm{mL} \mathrm{NaOCl}$

\section{ATP levels in dental stem cells decreased following $\mathrm{NaOCl}$ treatment}

As shown in Figure 2, ATP level was also downregulated by $\mathrm{NaOCl}$ treatment in concentration- and time-dependent manners (20 $\%$ at $0.005 \mathrm{mg} / \mathrm{mL}$ vs $50 \%$ at $0.01 \mathrm{mg} / \mathrm{mL}$ in 24 h group, $p<0.05 ; 20 \%$ for $2 \mathrm{~h}$ vs $80 \%$ for $24 \mathrm{~h}$ at $0.01 \mathrm{mg} / \mathrm{mL} \mathrm{NaOCl}, p<0.05)$. The ATP decrease in GMSCs was much smaller than in the other two cell lines, especially at lower $\mathrm{NaOCl}$ concentrations. As an example, ATP levels in DPSCs and PDLSCs decreased by nearly $50 \%$ at $0.01 \mathrm{mg} / \mathrm{mL}$ of $\mathrm{NaOCl}$ at $24 \mathrm{~h}$, when compared to $20 \%$ in GMSCs $(p<0.05)$. This suggests that GMSCs are more resistant than DPSCs and PDLSCs to $\mathrm{NaOCl}$-induced ATP loss.

Trop J Pharm Res, December 2018; 17(12): 2377 
A
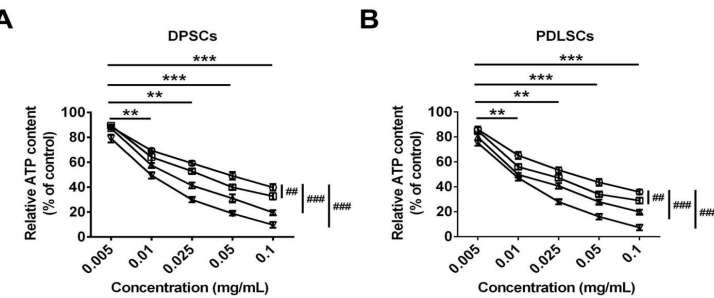

C

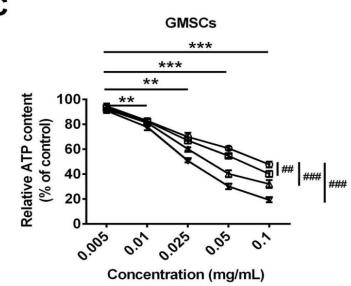

Figure 2: ATP levels in DPSCs (A), PDLSCs (B), and GMSCs $(C)$ after $\mathrm{NaOCl}$ treatment. The ATP contents of the treatment groups were compared with the untreated group. The untreated group was taken as control and each condition was tesfed in triplicate ${ }^{* *}$ or \#\#p<0.01,,** or \#\#\#p<0.001). : $4 \mathrm{~h} ; \Delta: 8 \mathrm{~h} ; \square: 4$ $\mathrm{h} ; \mathrm{o}: 2 \mathrm{~h}$

\section{$\mathrm{NaOCl}$ significantly affected dental stem cell proliferation}

To further investigate whether $\mathrm{NaOCl}$ attenuate stem cell proliferation, cells were incubated with $\mathrm{BrdU}$ and performed flow cytometry after $\mathrm{NaOCl}$ treatment. As shown in Figure $3 \mathrm{~A}$, the percentages of proliferative cells was significantly decreased upon $0.1 \mathrm{mg} / \mathrm{mL} \mathrm{NaOCl}$ treatment after $24 \mathrm{~h}(p<0.05)$. The proliferation of cells treated with other concentrations are shown in Figure 3B. Proliferation of DPSCs, PDLSCs, and GMSCs decreased in an $\mathrm{NaOCl}$ concentrationdependent manner. Importantly, $\mathrm{NaOCl}$ induced more prominent growth inhibition in DPSCs and PDLSCs than in GMSCs $(p<0.05)$, indicating that DPSCs and PDLSCs were more vulnerable to $\mathrm{NaOCl}$ treatment.

\section{$\mathrm{NaOCl}$ impaired dental stem cell differentiation}

Next, the expression of Stro- 1 was measured, a pluripotent marker for dental stem cells, and the differentiation markers DSPP, BSP, and OC to verify whether $\mathrm{NaOCl}$ impacted cell differentiation. As shown in Figure 4, significantly less Stro-1 was expressed in the experimental groups relative to the untreated groups ( $25 \%$ vs $10 \%$ for DPSCs and PDLSCs at D0, $p<0.05$ ). Similar to its effect on cell proliferation, $\mathrm{NaOCl}$ caused more prominent differentiation defect in DPSCs and PDLSCs than in GMSCs $(p<0.05)$. Similarly, DSPP, BSP, and OC levels were upregulated in a time-dependent manner. In DPSCs and PDLSCs, the downregulation in gene expression was much slower in the

experimental groups than the control groups (50 vs $90 \%$ for DPSCs at D7 and 50 vs $90 \%$ for PDLSCs, $p<0.05$ ), the changes of these three markers were faster in GMSCs. Only DSPP significantly decreased in treated cells (70 vs 90 $\%, p<0.05)$, while BSP levels remained unchanged (70 vs $70 \%, p>0.05$ ) and OC levels were enhanced in the experimental groups (70 vs $80 \%, p<0.05$ ), again suggesting less of an impact on GMSC proliferation.

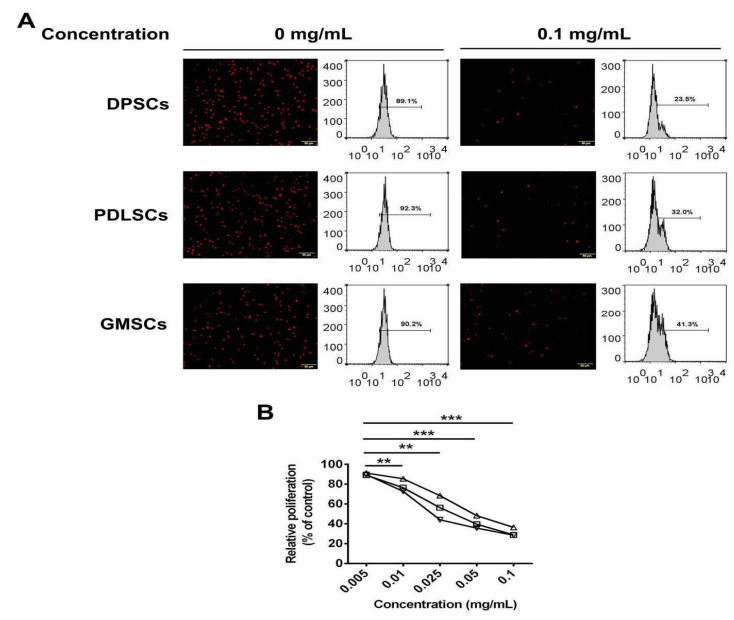

Figure 3: Flow cytometry data for DPSC, PDLSC, and GMSC proliferation. (A) The proliferation of three stem cell lines was assayed by fluorescence microscope (left) and flow cytometry (right). (B) Detained relative proliferation of the three stem cell lines treated with the $5 \mathrm{NaOCl}$ concentrations in $\left(\mathrm{A} / \mathrm{7} p<0.01,{ }^{* * *} p<\right.$ 0.001; $\Delta$ : GMSCs; $\sqsubset:$ PDLSCs; : WPSCs

\section{DISCUSSION}

Dental pulp stem cells, gingival mesenchymal stem cells, and periodontal ligament stem cells are similar to bone marrow mesenchymal stem cells in that they possess powerful proliferation and differentiation abilities, making them valuable resources for both endodontic and periodontal regeneration [8]. $\mathrm{NaOCl}$ was recently recommended as an effective irrigant and is extensively used in dentistry due to its functions in microbial control and tissue dissolution [17].

$\mathrm{NaOCl}$ exert antibacterial function through multiple ways. For instance, $\mathrm{NaOCl}$ can reduce surface tension of solution by functioning as a fat solvent [18]. It can also degrade dentin collagen by breaking the bonds between carbon atoms, thus disorganizing the protein primary structure [2]. Moreover, $\mathrm{NaOCl}$ denatures bacterial enzymes by releasing chlorine, a strong oxidant that can bind to the amino groups to generate chloramines, thus interfering with bacterial metabolism $[1,18]$. 


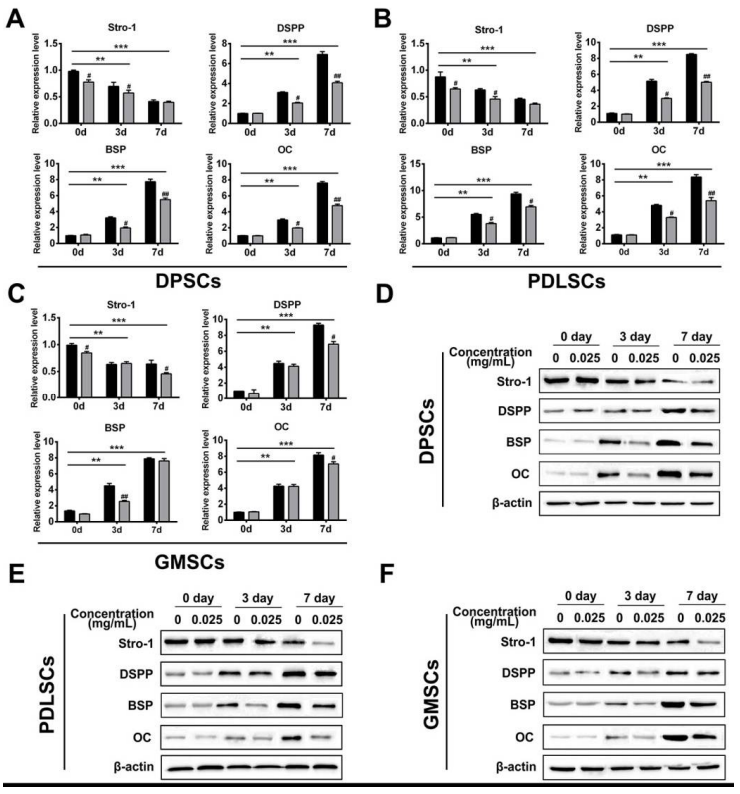

Figure 4: Differentiation marker expression levels in DPSCs, PDLSC, and GMSCs after $\mathrm{NaOCl}$ treatment on Days 0, 3, and 7. (A-C) qPCR analyses of Stro-1, DSPP, BSP, and OC in DPSCs (A), PDLSC (B), and GMSCs (C). The untreated group was taken as control, and results are expressed as fold change, $(p<$ 0.05). (D-F) Stro-1, DSPP, BSP, and OC protein levels in the three dental stem cell lines in $(A)$. Each condition was tested in triplicate $\left(\# p<0.05,{ }^{\star *}\right.$ or \#\# $p$ $\left.<0.01,{ }^{* * *} p<0.001\right)$. $: 0 \mathrm{mg} / \mathrm{mL} \mathrm{NaOCl} ; \square: 0.025$ $\mathrm{mg} / \mathrm{mL} \mathrm{NaOCl}$

Despite its antibacterial function, $\mathrm{NaOCl}$ can also induce some side effects such as canal tissue damage Furthermore, an additional chelating agent is needed to remove the smear layer [19]. Severe $\mathrm{NaOCl}$-induced necrosis has been observed both in preclinical and clinical studies and is most likely to occur in maxillary teeth [2022]. $\mathrm{NaOCl}$ was also reported to induce acute inflammation in vital tissues [23]. Although $6 \%$ $\mathrm{NaOCl}$ conditioned with dentin was reported to prevent DPSC differentiation both in vivo and in vitro [5,24], there have been few reports on the effect of $\mathrm{NaOCl}$ on PDLSCs and GMSCs, especially with regard to differentiation.

In the present study, the impact of $\mathrm{NaOCl}$ on GMSC proliferation and differentiation was investigated. The results showed that $\mathrm{NaOCl}$ negatively affected dental mesenchymal stem cell survival and differentiation, and dental stem cell cytotoxicity was directly correlated with the concentration and treatment time. These results are consistent with previous studies, suggesting that cell viability and differentiation decrease along with a higher $\mathrm{NaOCl}$ concentration and longer treatment [3]. The present research firstly demonstrated that $\mathrm{NaOCl}$ affects the proliferation and differentiation of PDLSCs and GMSCs. It is noteworthy that the change in ATP level and differentiation markers expression levels was less significant for GMSCs than the other two stem cells lines, indicating stronger tolerance of GMSCs to differentiation-induced stimuli. This might be attributable to their resistance to inflammatory stimuli.

A study demonstrated that GMSCs isolated from inflamed tissues displayed a normal phenotypic profile and developmental potential similar to cells obtained from healthy gingival tissues [25]. However, further investigation is needed to clarify the exact reasons for these observations. Taken together, a deteriorative effect of $\mathrm{NaOCl}$ on dental stem cell proliferation and differentiation was revealed in this study. It should therefore be used with caution during endodontic therapy.

\section{CONCLUSION}

$\mathrm{NaOCl}$ dose-dependently impairs the viability, proliferation and differentiation of dental stem cells. Thus, its toxicity to dental stem cells needs to be considered in clinical application.

\section{DECLARATIONS}

\section{Conflict of Interest}

No conflict of interest associated with this work.

\section{Contribution of Authors}

We declare that this work was done by the authors named in this article and all liabilities pertaining to claims relating to the content of this article will be borne by the authors. Shiqi Liu and Baorong Zhang designed all the experiments and revised the paper. Shaoping Fu, Chengyu Cui, Jinjuan Jiang, and Jian $\mathrm{Xu}$ performed the experiments, Pengyu Pan and Hanchao Zhai wrote the paper.

\section{REFERENCES}

1. Tan HK, Wheeler WB, Wei Cl. Reaction of chlorine dioxide with amino acids and peptides: kinetics and mutagenicity studies. Mutat Res 1987; 188(4): 259-266.

2. Ishizuka T, Kataoka H, Yoshioka T, Suda H, Iwasaki N, Takahashi $\mathrm{H}$, Nishimura F. Effect of $\mathrm{NaClO}$ treatment on bonding to root canal dentin using a new evaluation method. Dent Mater J 2001; 20(1): 24-33.

3. Alkahtani A, Alkahtany SM, Anil S. An in vitro evaluation of the cytotoxicity of varying concentrations of sodium hypochlorite on human mesenchymal stem cells. J Contemp Dent Pract 2014; 15(4): 473-481.

Trop J Pharm Res, December 2018; 17(12): 2379 
4. Park M, Pang NS, Jung IY. Effect of dentin treatment on proliferation and differentiation of human dental pulp stem cells. Restor Dent Endod 2015; 40(4): 290-298.

5. Galler KM, D'Souza RN, Federlin M, Cavender AC, Hartgerink JD, Hecker S, Schmalz G. Dentin conditioning codetermines cell fate in regenerative endodontics. J Endod 2011; 37(11): 1536-1541.

6. Martin DE, De Almeida JF, Henry MA, Khaing ZZ, Schmidt CE, Teixeira FB, Diogenes A. Concentrationdependent effect of sodium hypochlorite on stem cells of apical papilla survival and differentiation. J Endod 2014; 40(1): 51-55.

7. Verma K, Bains R, Bains VK, Rawtiya M, Loomba K, Srivastava SC. Therapeutic potential of dental pulp stem cells in regenerative medicine: An overview. Dent Res $J$ (Isfahan) 2014; 11(3): 302-308.

8. Rosa V, Botero TM, Nor JE. Regenerative endodontics in light of the stem cell paradigm. Int Dent $J$ 2011; 61 Suppl 1: 23-28.

9. Techawattanawisal W, Nakahama K, Komaki M, Abe M, Takagi $Y$, Morita I. Isolation of multipotent stem cells from adult rat periodontal ligament by neurosphereforming culture system. Biochem Biophys Res Commun 2007; 357(4): 917-923.

10. Gay IC, Chen S, MacDougall M. Isolation and characterization of multipotent human periodontal ligament stem cells. Orthod Craniofac Res 2007; 10(3): 149-160.

11. Fournier BP, Ferre FC, Couty L, Lataillade JJ, Gourven M, Naveau A, Coulomb B, Lafont A, Gogly $B$. Multipotent progenitor cells in gingival connective tissue. Tissue Eng Part A 2010; 16(9): 2891-2899.

12. Wang $F$, Yu M, Yan $X$, Wen $Y$, Zeng $Q$, Yue W, Yang $P$, Pei $X$. Gingiva-derived mesenchymal stem cellmediated therapeutic approach for bone tissue regeneration. Stem Cells Dev 2011; 20(12): 2093-2102.

13. Ferre FC, Larjava H, Loison-Robert LS, Berbar T, Owen GR, Berdal A, Cherifi H, Gogly B, Hakkinen L, Fournier $B P$. Formation of cartilage and synovial tissue by human gingival stem cells. Stem Cells Dev 2014; 23(23): 2895 2907.
14. Gao Y, Zhao G, Li D, Chen X, Pang J, Ke J. Isolation and multiple differentiation potential assessment of human gingival mesenchymal stem cells. Int J Mol Sci 2014; 15(11):20982-20996.

15. Zhang $Q$, Shi S, Liu Y, Uyanne J, Shi Y, Shi S, Le AD. Mesenchymal stem cells derived from human gingiva are capable of immunomodulatory functions and ameliorate inflammation-related tissue destruction in experimental colitis. J Immunol 2009; 183(12): 77877798.

16. Fawzy El-Sayed KM, Klingebiel P, Dorfer CE. Toll-like Receptor Expression Profile of Human Dental Pulp Stem/Progenitor Cells. J Endod 2016; 42(3): 413-417.

17. Kandaswamy $D$, Venkateshbabu $N$. Root canal irrigants. $J$ Conserv Dent 2010; 13(4):256-264.

18. Estrela C, Estrela CR, Barbin EL, Spano JC, Marchesan MA, Pecora JD. Mechanism of action of sodium hypochlorite. Braz Dent J 2002; 13(2): 113-117.

19. McComb $D$, Smith DC. A preliminary scanning electron microscopic study of root canals after endodontic procedures. J Endod 1975; 1(7): 238-242.

20. Kleier DJ, Averbach RE, Mehdipour O. The sodium hypochlorite accident: experience of diplomates of the American Board of Endodontics. J Endod 2008; 34(11): 1346-1350.

21. Gernhardt CR, Eppendorf K, Kozlowski A, Brandt M. Toxicity of concentrated sodium hypochlorite used as an endodontic irrigant. Int Endod J 2004; 37(4): 272-280.

22. Hulsmann M, Hahn W. Complications during root canal irrigation--literature review and case reports. Int Endod $J$ 2000; 33(3): 186-193.

23. Pashley EL, Birdsong NL, Bowman K, Pashley DH. Cytotoxic effects of $\mathrm{NaOCl}$ on vital tissue. J Endod 1985; 11(12): 525-528.

24. Casagrande L, Demarco FF, Zhang Z, Araujo FB, Shi S, Nor JE. Dentin-derived BMP-2 and odontoblast differentiation. J Dent Res 2010; 89(6): 603-608.

25. Ge S, Mrozik KM, Menicanin D, Gronthos S, Bartold PM. Isolation and characterization of mesenchymal stem cell-like cells from healthy and inflamed gingival tissue: potential use for clinical therapy. Regen Med 2012; 7(6): 819-832. 